\title{
Pengaruh Pupuk Nitrogen dan Pupuk Hayati Cair Terhadap Pertumbuhan dan Produksi Sayuran Daun Indigenous Tahunan
}

\section{Effect of Nitrogen and Biological Liquid Fertilizer to Growth and Production of Perennial Indigenous Leafy Vegetables}

\author{
Rista Delyani $^{1}$, Juang Gema Kartika ${ }^{1 *}$ \\ ${ }^{1}$ Departemen Agronomi dan Hortikultura,Fakultas Pertanian, Institut Pertanian Bogor \\ (Bogor Agricultural University), Jl. Meranti, Kampus IPB Darmaga, Bogor 16680, Indonesia \\ Telp. \& Faks.62-251-8629353 e-mail agronipb@indo.net.id \\ *Penulis untuk korespondensi: ika_juang@yahoo.com
}

Disetujui 14 November 2016/ Published online 16 Desember 2016

\begin{abstract}
The objectives of this research was to get the best rate of Nitrogen and the influence of biological liquid fertilizer to growth and production of two perennial indigenous leafy vegetables which can be harvest more than once. The research was conducted at IPB Research Station in Leuwikopo, Darmaga, Bogor from January to May 2012.The research was a parallel research with 2 comodities, kenikir and kemangi. This research arranged Block Randomized Design 2 factors for each comodity. The first factor was rate of Nitrogen with 4 levels, $0 \mathrm{~kg} \mathrm{ha}^{-1}, 45 \mathrm{~kg} \mathrm{ha}^{-1}, 90 \mathrm{~kg} \mathrm{ha}^{-1}$ and $135 \mathrm{~kg} \mathrm{ha}^{-1}$. The second factor was biological liquid fertilizer $(\mathrm{PCH})$ with 2 levels, with $\mathrm{PCH}$ and without PCH. Result showed that nitrogen increased production of two perennial indigenous leafy vegetables based on harvest weight of plot. Nitrogen can gave better production on environment that was not optimum. Recommended rate of nitrogen was $92.73 \mathrm{~kg} \mathrm{ha}$ for kenikir and $45 \mathrm{~kg} \mathrm{ha}^{-1}$ for kemangi. PCH didn't affect production of two perennial indigenous leafy vegetables.
\end{abstract}

Keywords : basil, kenikir, local microorganism, urea

\begin{abstract}
ABSTRAK
Penelitian ini bertujuan untuk mendapatkan dosis pupuk nitrogen terbaik dan mengetahui pengaruh pupuk cair hayati terhadap pertumbuhan dan produksi dua sayuran daun indigenous tahunan sebagai komoditas sayuran yang dapat dipanen lebih dari satu kali. Penelitian dilaksanakan kebun percobaan Lewikopo IPB, Dramaga, Bogor mulai pada bulan Januari sampai Mei 2012. Penelitian menggunakan percobaan paralel dengan 2 komoditas, yaitu kenikir dan kemangi. Penelitian disusun dengan Rancangan Kelompok Lengkap Teracak (RKLT) dengan 2 faktor untuk setiap komoditas. Faktor pertama dadalah dosis Nitrogen dengan 4 taraf, $0 \mathrm{~kg} \mathrm{ha}^{-1}, 45 \mathrm{~kg} \mathrm{ha}^{-1}, 90 \mathrm{~kg} \mathrm{ha}^{-1}$, dan $135 \mathrm{~kg} \mathrm{ha}$. Faktor keduan adalah Pupuk Cair Hayati (PCH) dengan 2 taraf, dengan PCH dan tanpa PCH. Hasil menunjukkan bahwa dosis Nitrogen dapat meningkatkan produksi dua sayuran daun indigenous pada bobot hasil panen per petak. Nitrogen dapat memberikan produksi lebih baik pada lingkungan tapi belum optimum. Dosis rekomendasi Nitrogen sebesar 92,73 $\mathrm{kg} \mathrm{ha}^{-1}$ untuk kenikir dan $45 \mathrm{~kg}$ hal untuk kemangi. PCH tidak memberikan pengaruh terhadap produksi dari dua sayuran daun indigenous.
\end{abstract}

Kata kunci : kemangi, kenikir, mikroorganisme lokal, urea 


\section{PENDAHULUAN}

Sayuran merupakan salah satu bahan pangan yang penting sebagai sumber vitamin, mineral, mineral, dan serat . Tingkat konsumsi sayuran di Indonesia masih tergolong rendah dan masih jauh di bawah rekomendasi FAO. Standar konsumsi sayuran yang ditetapkan oleh FAO adalah $73 \mathrm{~kg} / \mathrm{kapita} /$ tahun sedangkan pada tahun 2007 tingkat konsumsi sayuran penduduk Indonesia adalah sebesar $40.90 \mathrm{~kg} / \mathrm{kapita} / \mathrm{tahun}$ (Kementan, 2010).

Tingkat konsumsi yang rendah ini disebabkan karena kurangnya pemahaman masyarakat terhadap konsumsi sayuran serta pembudidayaan sayuran komersial yang hanya ada di daerah tertentu sehingga perlu dilakukan peningkatan produksi sayuran di Indonesia khususnya sayuran indigenous. Cara yang dapat dilakukan dalam perbaikan teknik budidaya adalah dengan menambah asupan hara bagi tanaman yang dapat dilakukan dengan memberikan pupuk atau menambah hara tersedia melalui pemanfaatan mikroorganisme lokal.

Sayuran indigenous adalah jenis sayuran atau varietas yang berasal dari suatu daerah atau tanaman yang dikenalkan pada suatu wilayah. Jenis atau varietas tersebut telah beradaptasi pada wilayah barunya meskipun bukan berasal daerah tersebut (Engle and Altoveros, 2000). Menurut Kusmana dan Suryadi (2004), Indonesia memiliki potensi untuk mengembangkan sayuran indigenous sebagai sayuran alternatif yang dapat memenuhi kebutuhan nutrisi (sumber protein, vitamin, dan mineral) dan permintaan pasar, serta dapat berkhasiat sebagai obat. Selain itu, sayuran indigenous juga dapat beradaptasi dengan baik dalam kondisi lingkungan yang relatif beragam. Sayuran indigenous berbeda dengan sayuran komersial dimana masih belum dibudidayakan secara luas.

Jenis sayuran indigenous yang banyak dibudidayakan adalah sayuran daun tahunan. Hal ini disebabkan karena sayuran tersebut mudah dibudidayakan dan panen yang dilakukan dapat lebih dari satu kali. Beberapa sayuran daun tahunan yang sering dikonsumsi adalah kemangi dan kenikir. Kemangi (Ocimum americanum L.) dan kenikir (Cosmos caudatus Kunth) adalah tanaman perdu yang banyak ditanam di pekarangan ((Sunarto, 1994) dan (Van Den Bergh, 1994)). Kedua tanaman ini memiliki kandungan gizi yang cukup baik seperti kandungan protein sekitar 3\% dari berat kering, vitamin, mineral dan serat serta memiliki khasiat obat.

Sayuran daun merupakan salah satu sayuran yang dikonsumsi saat berada pada fase vegetatif. Menurut Nazaruddin (1995) unsur hara yang memiliki peran utama saat fase vegetatif terutama untuk pertumbuhan daun adalah nitrogen. Kondisi nitrogen yang optimum penting dalam fase vegetatif dimana membangun perkembangan akar, batang dan daun dengan baik.

Tidak semua hara yang terdapat di tanah tersedia bagi tanaman. Ketidaktersediaan hara terjadi pada kondisi tanah tertentu namun dapat diatasi salah satunya dengan cara memanfaatkan mikroorganisme lokal untuk membantu mentransformasi hara dalam tanah menjadi bentuk yang dapat digunakan tanaman. Mikroorganisme lokal dalam tanah umumnya sedikit sehingga proses transformasi berjalan dengan lambat. Penambahan mikroorganisme lokal dapat dilakukan dengan memberikan pupuk cair hayati. Pupuk nitrogen dan mikroorganisme dalam tanah penting bagi pertumbuhan sayuran daun, oleh karena itu perlu dilakukan penelitian untuk mengetahui pengaruh dan mendapatkan dosis nitrogen dan mikroorganisme lokal terhadap pertumbuhan dan produktivitas dua sayuran daun indigenous tersebut.

Penelitian ini bertujuan untuk mendapatkan dosis pupuk nitrogen terbaik dan mengetahui pengaruh pupuk cair hayati terhadap pertumbuhan dan produksi dua sayuran daun indigenous tahunan sebagai komoditas sayuran yang dapat dipanen lebih dari satu kali.

\section{BAHAN DAN METODE}

Penelitian dilaksanakan di Kebun Percobaan Lewikopo, analisis hasil dilakukan di Laboratorium Produksi Departemen Agronomi dan Hortikultura, dan analisis tanah dilaksanakan di Laboratorium Tanah Departemen Ilmu Tanah dan Sumber Daya Lahan, Kampus IPB Darmaga. Penelitian ini berlangsung pada bulan Januari sampai Mei 2012.

Bahan yang digunakan terdiri atas bahan tanam (benih kemangi dan kenikir), kapur pertanian, pupuk kandang, arang sekam, pupuk Urea, pupuk SP-36, pupuk $\mathrm{KCl}$, dan pupuk cair hayati. Alat yang digunakan adalah alat budidaya pertanian, tray, penggaris, gembor, handsprayer, gunting pangkas, label, timbangan, oven dan alatalat lain yang menunjang pelaksanaan penelitian.

Penelitian ini merupakan penelitian parelel pada dua komoditas sayuran indigenous, kenikir dan kemangi. Penelitian dilaksanakan dengan menggunakan Rancangan Acak Kelompok (RAK) dengan dua faktor. Faktor pertama adalah yaitu dosis pupuk Nitrogen memiliki 4 taraf yaitu $0 \mathrm{~kg} \mathrm{ha}^{-1}, 45 \mathrm{~kg} \mathrm{ha}^{-1}, 90 \mathrm{~kg} \mathrm{ha}^{-1}$, dan $135 \mathrm{~kg} \mathrm{ha}^{-1}$. Faktor kedua adalah dosis pupuk cair hayati 
(PCH) dengan 2 taraf yaitu tidak diberi $\mathrm{PCH}$ dan diberi PCH. Setiap faktor diulang tiga kali sehingga terdapat 24 unit satuan percobaan untuk setiap komoditas. Masing-masing satuan percobaan diambil 5 tanaman contoh sehingga total tanaman contoh adalah 120 tanaman per komoditas.

Pengolahan data dilakukan dengan uji $\mathrm{F}$ pada sistem SAS (Statistical Analysis System), kemudian dilakukan uji lanjut Duncan Multiple Range Test (DMRT) pada taraf $5 \%$ pada perlakuan yang berpengaruh nyata.

Analisis tanah dilakukan sebelum pengolahan lahan. Penyemaian kenikir dilakukan pada tray semai sedangkan kemangi disemai di bedeng dengan campuran media tanam tanah, arang sekam, pupuk kandang dengan perbandingan $1: 1: 1$. Pengolahan lahan secara olah tanah sempurna lalu dibuat bedengan berukuran $3 \mathrm{~m}$ x $1.5 \mathrm{~m}$ sebanyak 24 petak per komoditas. Pupuk kandang diberikan dengan dosis $20 \mathrm{~kg} \mathrm{ha}^{-1}$. Tiga hari sebelum pindah tanam bedengan diberi pupuk $\mathrm{KCl}$ dengan dosis $225 \mathrm{~kg} \mathrm{ha}^{-1}$, SP-36 dengan dosis $375 \mathrm{~kg} \mathrm{ha}^{-1}$ serta kapur dengan dosis 1 ton $\mathrm{ha}^{-1}$ bersamaan dengan aplikasi PCH dengan dosis 3.3 liter ha ${ }^{-1}$. Aplikasi PCH menggunakan handsprayer.

Pindah tanam dilakukan saat kenikir berumur 3 MSS (minggu sesudah semai) sedangkan kemangi saat berumur 4 MSS. Bibit ditanam pada bedengan yang sudah disiapkan dengan jarak tanam $50 \mathrm{~cm}$ x $30 \mathrm{~cm}$. Perlakuan pemupukan nitrogen dilakukan saat tanam sesuai dosis masing-masing dengan cara diletakkan pada alur yang dibuat sekitar $7 \mathrm{~cm}$ di samping tanaman dengan dosis sesuai perlakuan. Pemeliharaan yang dilakukan meliputi penyulaman, pengendalian gulma, penyiraman, dan pemetikan calon bunga (khusus kemangi).

Panen pertama dilakukan pada saat tanaman berusia 6 MST. Kedua komoditas dipanen saat sudah menunjukkan indikator siap panen seperti tinggi tanaman sudah mencapai $30 \mathrm{~cm}$ untuk panen serta tunas yang dipanen sudah berukuran $20 \mathrm{~cm}$ (sekitar tiga buku) untuk kenikir dan $15 \mathrm{~cm}$ untuk kemangi dan masih menyisakan sekitar 2 calon tunas baru. Panen kedua juga dilakukan apabila cabang sudah memasuki kriteria panen yaitu pada 8 MST. Perlakuan nitrogen dan PCH dilakukan lagi saat panen pertama dengan dosis nitrogen yang sama dengan saat pindah tanam dan dosis PCH menjadi $6.61 \mathrm{ha}^{-1}$ pada perlakuan dengan $\mathrm{PCH}$.

Analisis tanah meliputi $\mathrm{pH}$ dan analisis kandungan hara seperti kandungan $\mathrm{N}, \mathrm{P}, \mathrm{K}$, dan $\mathrm{C} / \mathrm{N}$ ratio. Pengamatan pertumbuhan yaitu tinggi tanaman, jumlah cabang primer, jumlah cabang sekunder (pada kemangi), diamati sejak 1 MST hingga 6 MST, kemudian pertambahan panjang cabang primer, jumlah daun, pertambahan cabang sekunder (pada kenikir), pertambahan cabang tersier (pada kemangi) dilakukan pada 7 dan 8 MST. Pengamatan ILD dilakukan saat panen pertama (6 MST) dan panen kedua (8 MST). Pengamatan panen meliputi bobot basah/tanaman, bobot kering/tanaman, serta bobot panen/bedeng, diamati pada panen pertama dan kedua.

\section{HASIL DAN PEMBAHASAN}

\section{Kondisi Umum}

Benih kemangi diperoleh dari SPI (Serikat Petani Indonesia) sedangkan kenikir diperoleh dari Balitro (Balai Penelitian Tanaman Obat). Penyemaian tanaman dilakukan di bawah rumah plastik di daerah Babakan, Darmaga. Adanya pembatas berupa bangunan menyebabkan tanaman hanya mendapatkan sinar matahari sejak siang hingga sore hari saja. Penyiraman bibit dilakukan dengan menggunakan handsprayer pada pagi dan sore hari. Penyulaman benih hanya dilakukan pada kemangi karena adanya serangan hama semut. Aplikasi furadan diberikan pada persemaian kedua kemangi.

Pertumbuhan tanaman awal penanaman di lapang menunjukkan kondisi yang kurang baik karena kurangnya curah hujan pada saat tanaman siap dipindahtanamkan. Curah hujan yang sedikit dan ketersedian air yang terbatas saat pindah tanam membuat tanaman harus disiram minimal satu hari sekali. Hal ini cukup efektif mengurangi tingkat kematian tanaman, terlihat dari persentase hidup tanaman kenikir dan kemangi yang baik yaitu $98.44 \%$ dan $86.98 \%$. OPT yang menyerang tanaman kemangi yaitu belalang. Selain itu tanaman kenikir juga menunjukkan adanya gejala yang ditandai dengan mengeringnya daun dan tunas muda, namun serangan tersebut tidak menimbulkan kerusakan permanen pada tanaman. Gulma dominan yaitu dari golongan daun lebar. Kenikir mulai memasuki masa generatif saat 6 MST sedangkan sebagian kecil kemangi sudah mulai berbunga saat $3 \mathrm{MST}$. Hal ini diduga karena tanaman sudah mengalami stress air pada awal pertumbuhan. Kedua komoditas dipindahtanamkan pada bulan Maret dimana curah hujan pada bulan tersebut adalah $136.5 \mathrm{~mm} / \mathrm{bulan}$. Kurang tersedianya air bagi tanaman mengakibatkan tanaman menginduksi pembungaan lebih awal. 
Bul. Agrohorti 4 (3): 335-342 (2016)

Berdasarkan hasil rekapitulasi sidik ragam kenikir (Tabel 1) perlakuan nitrogen memberikan pengaruh nyata pada pertambahan cabang kenikir pada 3 MST serta bobot basah per bedeng pada panen kedua. Perlakuan $\mathrm{PCH}$ memberikan pengaruh nyata pada pertambahan jumlah daun pada cabang sekunder kenikir saat 7 MST. Interaksi antara kedua perlakuan tidak berpengaruh terhadap semua peubah.

Tabel 1. Rekapitulasi sidik ragam tanaman kenikir

\begin{tabular}{|c|c|c|c|c|c|c|}
\hline \multirow{2}{*}{ No } & \multirow{2}{*}{ Peubah } & \multirow{2}{*}{ MST } & \multicolumn{3}{|c|}{ Uji F } & \multirow{2}{*}{$\mathrm{KK}(\%)$} \\
\hline & & & $\mathrm{N}$ & $\mathrm{PCH}$ & $\mathrm{N} * \mathrm{PCH}$ & \\
\hline \multicolumn{7}{|c|}{ Pertumbuhan } \\
\hline \multirow[t]{6}{*}{1} & Tinggi & 1 & tn & tn & tn & 22.23 \\
\hline & tanaman & 2 & tn & tn & tn & 18.51 \\
\hline & & 3 & tn & tn & tn & 13.40 \\
\hline & & 4 & tn & tn & tn & 10.32 \\
\hline & & 5 & tn & tn & tn & 9.60 \\
\hline & & 6 & tn & tn & tn & 15.89 \\
\hline \multirow[t]{5}{*}{2} & Jumlah cabang & 2 & tn & tn & tn & $8.96^{(2)}$ \\
\hline & primer & 3 & $*$ & tn & tn & 16.02 \\
\hline & & 4 & tn & tn & tn & 9.25 \\
\hline & & 5 & tn & tn & tn & 9.03 \\
\hline & & 6 & tn & tn & tn & 5.85 \\
\hline \multirow[t]{2}{*}{3} & ILD (Indeks & 6 & $\operatorname{tn}$ & tn & tn & $26.31^{(1)}$ \\
\hline & Luas Daun) & 8 & tn & tn & tn & $24.64^{(1)}$ \\
\hline \multirow[t]{2}{*}{4} & + Panjang & 7 & tn & tn & tn & 16.73 \\
\hline & cabang & 8 & tn & tn & tn & 34.71 \\
\hline \multirow[t]{2}{*}{5} & + Jumlah daun & 7 & tn & tn & tn & 15.26 \\
\hline & pd cabang & 8 & tn & $\operatorname{tn}$ & tn & 24.28 \\
\hline 6 & + Cabang & 7 & tn & $*$ & tn & 14.35 \\
\hline \multirow[t]{2}{*}{7} & Bobot basah & 6 & tn & tn & tn & 26.01 \\
\hline & per tanaman & 8 & tn & tn & tn & 23.00 \\
\hline \multirow[t]{2}{*}{8} & Bobot kering & 6 & $\operatorname{tn}$ & tn & tn & 25.75 \\
\hline & per tanaman & 8 & tn & tn & tn & 24.67 \\
\hline \multirow[t]{2}{*}{9} & Bobot panen & 6 & tn & tn & tn & 17.12 \\
\hline & Per bedeng & 8 & $*$ & tn & tn & 15.12 \\
\hline
\end{tabular}

${ }^{a}$ tn $=$ tidak berbeda nyata pada uji $\mathrm{F} 5 \%: *$ berbeda nyata pada uji F 5\% : KK: koefisien keragaman : $\left(^{1}\right)$ hasil transformasi $\sqrt{ } \mathrm{X}:\left({ }^{2}\right)$ hasil tarasformasi $\sqrt{ } \mathrm{x}+1$

Hasil penelitian menunjukkan perlakuan pupuk nitrogen tidak berpengaruh nyata terhadap tinggi tanaman kemangi dan kenikir, jumlah cabang primer kemangi, pertambahan jumlah daun kenikir, pertambahan panjang cabang kenikir, pertambahan jumlah cabang sekunder kenikir. Hal ini sesuai dengan yang dilakukan oleh Lestari (2008) dimana tinggi tanaman kenikir dan kemangi, jumlah cabang kenikir dan kemangi serta jumlah daun kenikir tidak dipengaruhi oleh pemupukan. Penelitian Rahanita (2009) juga memperoleh hasil dimana tinggi dan jumlah daun kenikir tersebut tidak dipengaruhi oleh pemupukan. Kedua penelitian tersebut juga memiliki kemiripan kondisi lingkungan tumbuh dimana terdapat kendala pada ketersediaan air di awal pertumbuhan.
Tabel 2. Rekapitulasi sidik ragam kemangi

\begin{tabular}{|c|c|c|c|c|c|c|}
\hline \multirow{2}{*}{ No } & \multirow{2}{*}{ Peubah } & \multirow{2}{*}{ MST } & \multicolumn{3}{|c|}{ Uji F } & \multirow{2}{*}{$\mathrm{KK}(\%)$} \\
\hline & & & $\mathrm{N}$ & $\mathrm{PCH}$ & $\mathrm{N} * \mathrm{PCH}$ & \\
\hline \multirow[t]{6}{*}{1} & Tinggi & 1 & tn & $\operatorname{tn}$ & tn & 12.10 \\
\hline & tanaman & 2 & tn & tn & $\operatorname{tn}$ & 9.29 \\
\hline & & 3 & tn & tn & tn & 7.14 \\
\hline & & 4 & tn & $*$ & $*$ & 5.74 \\
\hline & & 5 & tn & $*$ & $*$ & 5.74 \\
\hline & & 6 & tn & $\operatorname{tn}$ & $*$ & 6.58 \\
\hline \multirow[t]{4}{*}{2} & Jumlah cabang & 1 & tn & tn & tn & 33.12 \\
\hline & primer & 2 & tn & $\operatorname{tn}$ & tn & 12.67 \\
\hline & & 3 & tn & tn & tn & 5.86 \\
\hline & & 4 & tn & tn & tn & 4.53 \\
\hline \multirow[t]{4}{*}{3} & Jumlah cabang & 3 & $* *$ & $\operatorname{tn}$ & tn & 22.74 \\
\hline & sekunder & 4 & tn & $\operatorname{tn}$ & tn & 13.93 \\
\hline & & 5 & th & $*$ & $* *$ & 7.44 \\
\hline & & 6 & $*$ & tn & $* *$ & 6.86 \\
\hline \multirow[t]{2}{*}{4} & ILD (Indeks & 6 & tn & tn & tn & 36.01 \\
\hline & Luas Daun) & 8 & tn & tn & tn & 35.04 \\
\hline \multirow[t]{2}{*}{5} & + cabang tersier & 7 & tn & $\operatorname{tn}$ & tn & $29.28^{(1)}$ \\
\hline & & 8 & tn & $\operatorname{tn}$ & tn & $19.07^{(2)}$ \\
\hline \multicolumn{7}{|c|}{ Produksi } \\
\hline \multirow[t]{2}{*}{6} & Bobot basah per & 6 & tn & $\operatorname{tn}$ & tn & 26.01 \\
\hline & tanaman & 8 & tn & $\operatorname{tn}$ & tn & 23.00 \\
\hline 7 & Bobot kering & 6 & tn & tn & tn & 25.75 \\
\hline 8 & Bobot panen per & 6 & tn & tn & $*$ & 17.12 \\
\hline \multicolumn{7}{|c|}{ Keterangan: $\mathrm{tn}=$ tidak berbeda nyata pada uji F 5\%: $*$} \\
\hline
\end{tabular}

Pemupukan nitrogen tidak memberikan pengaruh pada pertambahan jumlah daun kenikir. Hal ini diduga akibat adanya hambatan fungsi hormon sitokinin oleh asam absisat (ABA). Menurut Fisher dan Goldsworthy (1992), hormon sitokinin dapat bertanggung jawab untuk mengatur perkembangan daun menurut kondisi tanah seperti ketersediaan air dan mineralisasi nitrogen. Namun hormon sitokinin juga dapat dihambat oleh asam absisat yang dapat muncul akibat adanya cekaman pada tanaman. Cekaman yang terdapat pada penelitian ini adalah cekaman kekeringan. Perlakuan dosis pupuk nitrogen 90 $\mathrm{kg} \mathrm{ha}^{-1} \mathrm{~N}$ meningkatkan jumlah cabang sekunder kemangi pada umur 3 MST (Tabel 3) sedangkan pada kenikir pengaruh nitrogen terlihat pada umur 3 MST dimana pemberian $45 \mathrm{~kg} \mathrm{ha}^{-1} \mathrm{~N}$ meningkatkan jumlah cabang primer (Tabel 5). Hal ini diduga karena mulai 3 MST (bulan April) curah hujan sudah mulai cukup tinggi sekitar $389.5 \mathrm{~mm} /$ bulan sementara percabangan sangat tergantung pada faktor-faktor yang menguntungkan pertumbuhan vegetatif yang cepat, terutama kelembaban dan nitrogen yang cukup (Gardner et al., 2008).

Interaksi pupuk nitrogen dan $\mathrm{PCH}$ terhadap jumlah cabang sekunder pada umur 3,5 dan 6 MST terlihat pada Tabel 4. Jumlah cabang 
sekunder terbanyak pada umur $5-6$ MST diperoleh pada perlakuan $45 \mathrm{~kg} \mathrm{ha}^{-1} \mathrm{~N}$ dengan PCH yaitu 142.93 cabang pada 5 MST dan 151.33 cabang pada 6 MST, namun pada umur 5 MST menunjukkan tidak berbeda nyata terhadap pemberian PCH meskipun pada dosis nitrogen yang sama.

Tabel 3. Pengaruh pupuk nitrogen dan pupuk cair hayati terhadap jumlah cabang sekunder kemangi

\begin{tabular}{|c|c|c|c|c|}
\hline \multirow{2}{*}{ Perlakuan } & \multicolumn{4}{|c|}{ Umur tanaman (MST) } \\
\hline & 3 & 4 & 5 & 6 \\
\hline \multicolumn{5}{|c|}{ Nitrgen $\left(\mathrm{kg} \mathrm{ha}^{-1)}\right.$} \\
\hline 0 & $29.37 b$ & 96.93 & 133.93 & 135.60 \\
\hline 45 & $48.00 \mathrm{a}$ & 116.07 & 133.87 & 138.00 \\
\hline 90 & $51.93 \mathrm{a}$ & 108.13 & 122.67 & 125.40 \\
\hline 135 & $46.47 \mathrm{a}$ & 107.53 & 127.87 & 130.27 \\
\hline \multicolumn{5}{|l|}{$\mathrm{PCH}(\%)$} \\
\hline 0 & 41,70 & 112.20 & $135.07 \mathrm{a}$ & 135.50 \\
\hline 100 & 46.37 & 102.13 & $124.10 \mathrm{~b}$ & 129.13 \\
\hline
\end{tabular}

Tabel 4. Interaksi pupuk nitrogen dan pupuk cair hayati terhadap jumlah cabang sekunder kemangi

\begin{tabular}{|c|c|c|c|c|c|}
\hline \multirow[b]{2}{*}{ Perlakuan } & \multicolumn{5}{|c|}{ Umur tanaman (MST) } \\
\hline & 2 & 3 & 4 & 5 & 6 \\
\hline \multicolumn{6}{|c|}{ Nitrgen $\left(\mathrm{kg} \mathrm{ha}^{-1)}\right.$} \\
\hline 0 & 0.10 & $4.20 \mathrm{~b}$ & 9.53 & 15.10 & 20.93 \\
\hline 45 & 0.27 & $5.87 \mathrm{a}$ & 10.67 & 16.97 & 22.73 \\
\hline 90 & 0.23 & $5.10 \mathrm{ab}$ & 10.53 & 15.67 & 20.07 \\
\hline 135 & 0.00 & $5.43 \mathrm{a}$ & 10.20 & 16.60 & 22.30 \\
\hline \multicolumn{6}{|l|}{ PCH (\%) } \\
\hline 0 & 0.08 & 4.83 & 10.25 & 16.10 & 21.75 \\
\hline 100 & 0.22 & 5.47 & 10.22 & 16.12 & 22.27 \\
\hline Keterangan : & $\begin{array}{l}\text { Nilai } \\
\text { (Nitrc } \\
\text { kolon } \\
\text { berbe } \\
\text { taraf }\end{array}$ & $\begin{array}{l}\text { ang dii } \\
\text { en) yan }\end{array}$ & i huru & $\begin{array}{l}\text { kapital } \\
\text { u huruf } \\
\text { menunju } \\
\text { n uji D }\end{array}$ & $\begin{array}{l}\text { pada baris } \\
\text { kecil pada } \\
\text { kkan tidak } \\
\text { MRT pada }\end{array}$ \\
\hline
\end{tabular}

Jumlah cabang primer hanya dipengaruhi oleh pupuk nitrogen pada umur 3 MST. Pemberian dosis $45 \mathrm{~kg} \mathrm{ha}^{-1}$ dan $135 \mathrm{~kg} \mathrm{ha}^{-1}$ memberikan hasil yang lebih baik dibandingkan tanpa pemberian pupuk namun tidak berbeda secara statistik dengan $90 \mathrm{~kg} \mathrm{ha}^{-1}$. Perbedaan ketersediaan air pada awal dan akhir masa vegetatif menimbulkan ketidakseragaman pertumbuhan tanaman tersebut. Penelitian Lestari (2008) juga menunjukkan dimana perlakuan memberikan hasil yang tidak berbeda pada bobot basah per tanaman kenikir namun berbeda nyata pada bobot panen per bedeng.

Meskipun banyak peubah pengamatan yang menunjukkan tidak berbeda nyata secara statistik, namun berdasarkan data rata-rata nilai tengah pengamatan, perlakuan pupuk nitrogen 0 $\mathrm{kg} \mathrm{ha}^{-1}$

pada kedua komoditas secara konsisten memberikan hasil yang paling sedikit pada beberapa parameter yaitu tinggi tanaman, indeks luas daun, bobot basah per tanaman, bobot kering per tanaman serta bobot panen per bedeng pada kenikir, serta parameter bobot basah per tanaman, bobot kering per tanaman dan bobot panen per bedeng pada kemangi. Hal tersebut dapat diasumsikan bahwa pemberian pupuk nitrogen mampu memberikan ketersediaan hara yang lebih baik daripada tanpa dipupuk nitrogen.

Tabel 5. Pengaruh pupuk nitrogen dan pupuk cair hayati terhadap jumlah cabang primer kenikir

\begin{tabular}{rcccc}
\hline \multirow{2}{*}{$\begin{array}{c}\text { PCH } \\
(\%)\end{array}$} & \multicolumn{4}{c}{ Nitrogen $\left(\mathrm{kg} \mathrm{ha}^{-1}\right)$} \\
\cline { 2 - 5 } & 0 & \multicolumn{4}{c}{45} & 90 & 135 \\
\hline 0 & $140.20 \mathrm{Aa}$ & $124.80 \mathrm{Aa}$ & $132.00 \mathrm{~A}$ & $142.27 \mathrm{~A}$ \\
100 & $126.68 \mathrm{Bb}$ & $142.93 \mathrm{Aa}$ & $113.33 \mathrm{ca}$ & $113.47 \mathrm{C}$ \\
\hline \multicolumn{5}{c}{$-----------------6 \mathrm{MST}---------------$} \\
\hline 0 & $143.07 \mathrm{Aa}$ & $124.67 \mathrm{Ab}$ & $130.67 \mathrm{~A}$ & $143.60 \mathrm{~A}$ \\
100 & $128.13 \mathrm{Ba}$ & $151.33 \mathrm{Aa}$ & $120.13 \mathrm{~B}$ & $116.93 \mathrm{~B}$ \\
\hline Keterangan : & angka yang diikuti dengan huruf yang & yan & berbeda pada kolom yang sama \\
\multicolumn{5}{c}{ menunjukkan berbeda nyata pada uji DMRT } \\
& taraf 5 \% &
\end{tabular}

Hasil regresi pada bobot panen per bedeng pada panen kedua kenikir menunjukkan bahwa peningkatan dosis pupuk nitrogen menyebabkan bobot panen per bedeng kenikir juga akan meningkat sampai titik tertentu kemudian menurun dengan semakin meningkatnya dosis pupuk nitrogen (Gambar 1).

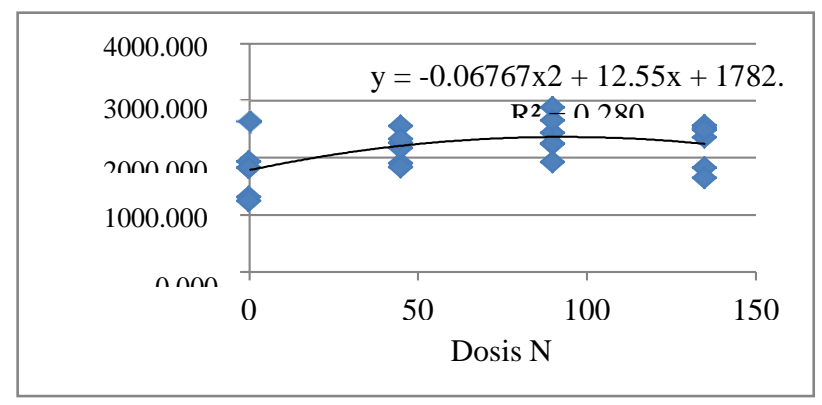

Gambar 1. Respon bobot bedeng panen kedua kenikir terhadap dosis Pupuk nitrogen

Garis regresi pada panen kedua menunjukkan garis yang kuadratik. Dari persamaan regresi $\mathrm{y}=-0.06767 \mathrm{x}^{2}+12.55 \mathrm{x}+$ 1782 diperoleh dosis pemupukan nitrogen yang memberikan produksi kenikir maksimal adalah $92.73 \mathrm{~kg} \mathrm{ha}^{-1}$. 
Seperti halnya kenikir, bobot basah per tanaman dan bobot kering per tanaman kemangi tidak dipengaruhi oleh perlakuan, namun terdapat pengaruh pada bobot panen per bedeng (Tabel 6). Interaksi pemupukan nitrogen dan $\mathrm{PCH}$ pada bobot panen per bedeng memberikan nilai terbesar pada pemberian $45 \mathrm{~kg} \mathrm{ha}^{-1} \mathrm{~N}$ tanpa $\mathrm{PCH}$ yaitu sebesar $1641.7 \mathrm{~g}$ (Tabel 7).

Tabel 6. Pengaruh pupuk nitrogen dan pupuk cair hayati terhadap bobot panen per bedeng kemangi

\begin{tabular}{|c|c|c|}
\hline \multirow{2}{*}{ Perlakuan } & Panen 1 & Panen 2 \\
\hline & \multicolumn{2}{|c|}{----------g--------- } \\
\hline Ni trogen $\left(\mathrm{kg} \mathrm{ha}^{-1}\right)$ & & \\
\hline 0 & 1115.60 & 2812.60 \\
\hline 45 & 1414.60 & 3436.30 \\
\hline 90 & 1341.60 & 3280.20 \\
\hline 135 & 1360.00 & 2246.70 \\
\hline $\mathrm{PCH}$ & & \\
\hline $\begin{array}{r}0 \\
100\end{array}$ & $\begin{array}{l}1319.35 \\
1296.57\end{array}$ & $\begin{array}{l}3471.8 \mathrm{a} \\
2966.1 \mathrm{~b}\end{array}$ \\
\hline
\end{tabular}

Keterangan : angka yang diikuti dengan huruf yang berbeda pada kolom yang sama menunjukkan berbeda nyata pada uji DMRT taraf $5 \%$.

Bobot basah menjadi karakter penting yang menentukan nilai ekonomi suatu komoditas hortikultura. Bobot basah, terutama pada sayuran juga sering disebut dengan produksi karena merupakan edible portion (bagian yang dapat dikonsumsi). Produksi terlihat dari parameter bobot panen per bedeng pada kedua panen. Produksi kenikir untuk dua kali panen berkisar antara $500-2,500 \mathrm{~g}$ sedangkan produksi kemangi berkisar antara 1,000 - 3,500 g meskipun kebutuhan hara keduanya berbeda (Tabel 7).

Tabel 7. Interaksi pupuk Nitrogen dan Pupuk Cair Hayati terhadap bobot panen per bedeng kemangi pada panen pertama

\begin{tabular}{|c|c|c|c|c|}
\hline \multirow{2}{*}{$\begin{array}{c}\mathrm{PCH} \\
(\%)\end{array}$} & \multicolumn{4}{|c|}{ Nitrogen $\left(\mathrm{kg} \mathrm{ha}^{-1}\right)$} \\
\hline & 0 & 45 & 90 & 135 \\
\hline \multicolumn{5}{|c|}{-------------------g----------------------- } \\
\hline 0 & & $1641.7 \mathrm{Aa}$ & $1278.1 \mathrm{Aab}$ & \\
\hline 100 & $1034.5 \mathrm{Aa}$ & $1187.6 \mathrm{Aa}$ & $1405.1 \mathrm{Aa}$ & $1559.0 \mathrm{Aa}$ \\
\hline \multicolumn{5}{|c|}{$\begin{aligned} \text { Keterangan : Nilai yang diikuti huruf kapital pada baris } \\
\text { (pupuk nitrogen) yang sama atau huruf kecil } \\
\text { pada kolom (PCH) yang sama menunjukkan } \\
\text { tidak berbeda nyata berdasarkan uji DMRT } \\
\text { pada taraf 5\%. }\end{aligned}$} \\
\hline
\end{tabular}

Kebutuhan hara kenikir sekitar dua kali kebutuhan hara kemangi. Hal ini disebabkan oleh perbedaan habitus kedua tanaman. Tinggi kedua komoditas pada $6 \mathrm{MST}$, tinggi kenikir mendekati $50 \mathrm{~cm}$ sedangkan kemangi hanya mencapai 30 $\mathrm{cm}$. Hal ini menunjukkan bahwa kenikir memerlukan input yang lebih tinggi untuk memproduksi biomassa sedangkan kemangi lebih efiesien dalam memanfaatkan unsur haranya.

\section{KESIMPULAN}

Pemupukan nitrogen yang mampu memberikan produksi paling baik dengan kondisi tumbuh yang tidak optimum (kekurangan air pada awal pertumbuhan tanaman) adalah 92.73 kg ha-1 pada kenikir dan $45 \mathrm{~kg} \mathrm{ha}^{-1}$ pada kemangi. Pemberian pupuk cair hayati tidak mempengaruhi produksi sayuran daun indigenous tahunan (kenikir dan kemangi).

\section{DAFTAR PUSTAKA}

Engle, L.M., Altoveros, N.C. 2000. Collection, Conservation and Utilization of Indigenous Vegetables. Shanhua: AVRDC.

Fisher, N.M., 1992. Pertumbuhan dan perkembangan tanaman : fase vegetatif. Dalam N.M Fisher dan P.R. Goldsworthy (Eds.). Fisiologi Tanaman Budidaya Tropik. Fakultas Pertanian Universitas Gajah Mada. Yogyakarta.

Gardner, P.F., Pearce, R.B., Mitchell, R.L. 2008. Fisiologi Tanaman Budidaya (diterjemahkan dari : Physiology of Crop Plants, penerjemah : Herawati Susilo). Jakarta (ID): Universitas Indonesia.

[Kementan] Kementrian Pertanian. 2010. Konsumsi sayur masyarakat Indonesia di bawah rekomendasi FAO [internet]. [diunduh 18 Mei 2011]. www.agro.agroprima. com.

Kusmana, Suryadi. 2004. Mengenal Sayuran Indijenes. Hortikultura. Bandung (ID): Badan Penelitiandan Pengembangan Pertanian.

Lestari, M.A. 2008. Pengaruh pemupukan terhadap pertumbuhan dan produktivitas beberapa sayuran indigenous [Skripsi]. Bogor (ID): Institut Pertanian Bogor.

Nazaruddin. 1995. Budidaya dan Pengaturan Panen Sayuran Dataran Rendah. Jakarta (ID): Penebar Swadaya. 
Rahanita, P. 2009. Pengaruh pupuk organik pada pertumbuhan pan hasil tanaman kenikir (Cosmos caudatus) dan katuk (Sauropus androgynus) [Skripsi]. Bogor (ID). Institut Pertanian Bogor.

Sunarto, A.T. 1994. Ocimum americanum L. In : J. S. Siemonsma and K. Piluek (Eds.). Bogor (ID): Plant Resources of SouthEast Asia. Prosea. Vegetables.
Van den Bergh, M.H. 1994. Cosmos caudatus Kunth., In : J. S. Siemonsma and K. Piluek (Eds.). Bogor (ID): Plant Resources of South-East Asia. Prosea. Vegetables. 